\title{
Gastrointestinal Yerleşimli Lipomalar: 19 Olgunun Retrospektif Analizi
}

\author{
Mine ÖZŞEN ${ }^{1}$, Ömer YERCI $^{1}$, Nesrin UĞRAŞ ${ }^{1}$, Özgen IŞIK ${ }^{2}$, Tuncay YILMAZLAR ${ }^{2}$
}

1 Bursa Uludağ Üniversitesi Tıp Fakültesi, Tıbbi Patoloji Anabilim Dalı, Bursa.

2 Bursa Uludağ Üniversitesi Tıp Fakültesi, Genel Cerrahi Anabilim Dalı, Bursa.

\section{ÖZET}

Bu tanımlayıcı çalışmada gastrointestinal sistem yerleşimli lipoma tanısı alan olguların sunulması ve bu tümörlerin klinikopatolojik özelliklerinin literatür bilgileri eşliğinde değerlendirilmesi amaçlanmıştır. Çalışmamızda Tıbbi Patoloji Anabilim Dalı arşivi taranarak gastrointestinal sistem yerleşimli lipoma tanısı alan 19 olgu retrospektif olarak incelendi. Olguların 11'i kadın (\%57,9), 8'i erkekti (\%42,1). Ortalama yaş değeri 62,3 yaş olarak saptandı (yaş dağıllımı 36-78). 19 olgunun 14'ü kolon, 3'ü ince barsak, l'i mide ve 1'i rektum yerleşimliydi. Angiolipoma tanısı alan inen kolon yerleşimli tek olgu dışında kalan tüm olgular klasik lipoma morfolojsindeydi. Genellikle insidental olarak saptanan lipomalar, obtrüksiyon, intusepsiyon ve kanama gibi ciddi gastrointestinal semptomlara yol açabilen, adenokarsinomalara eşlik edebilen ve malignitelerle ayırıcı tanısı yapılması gereken tümörlerdir. Tüm olgular operasyon öncesinde uygun radyolojik ve endoskopik yöntemlerle incelenmeli ve her olgu için en uygun tedavi seçeneği değerlendirilmelidir.

Anahtar Kelimeler: Gastrointestinal sistem. Mezenkimal tümörler. Lipoma. Tedavi. Semptom.

Lipomas of the Gastrointestinal Tract: Retrospective Analysis of 19 Cases

\begin{abstract}
In this descriptive study, we aimed to present lipoma cases diagnosed in the gastrointestinal tract and to evaluate the clinicopathological features of these tumors based on literature review. In this study, patient files of 19 cases diagnosed with lipoma of the gastrointestinal tract were retrospectively reviewed from the archives of the Department of Pathology of Faculty of Medicine. Eleven of the cases were female (\%57,9), and eight (42,1\%) were male. The mean age was 62,3 years (range: 36-78 years). Of the 19 cases, 14 were located in the colon, 3 in the small intestine, 1 in the stomach and 1 in the rectum. The classical morphology of lipoma was seen in all cases except one case that was diagnosed with angiolipoma located in the descending colon. Generally, incidentally detected lipomas, which can be accompanied by adenocarcinomas, are tumors that can lead to gastrointestinal symptoms such as obstruction, intussusception and bleeding, and differential diagnosis of malignancies is required. All cases should be examined by appropriate radiological and endoscopic methods before operation and the most appropriate treatment option should be evaluated for each case.
\end{abstract}

Key Words: Gastrointestinal tract. Mesenchymal tumors. Lipoma. Treatment. Symptoms.

Geliş Tarihi: 29.Nisan.2021

Kabul Tarihi: 26.Ağustos.2021

Dr. Mine ÖZŞEN

Bursa Uludağ Üniversitesi Tıp Fakültesi, Tıbbi Patoloji Anabilim Dalı,

Bursa

Tel. 05321601737

E-posta: m.isikoglu@hotmail.com

Yazarların ORCID ID Bilgisi:

Mine ÖZSSEN: 0000-0002-5771-7649

Ömer YERCi: 0000-0001-7118-5258

Nesrin UĞRAŞ: 0000-0003-0127-548X

Özgen IŞIK: 0000-0002-9541-5035

Tuncay YILMAZLAR: 0000-0003-1924-0795
Gastrointestinal lipomalar, fibröz kapsül ile çevirili matür yağ dokusundan oluşan, genellikle submukozal yerleşimli, yavaş büyüyen, benign mezenkimal tümörlerdir ${ }^{1}$. Kolonda adenomatöz poliplerden sonra en sik görülen ikinci benign tümörler olan lipomalar, gastrointestinal sistemin (GİS) benign lezyonlarının \% 4'ünü oluştururken, insidansı çeşitli klinik çalışmalarda ve otopsi serilerinde \% 0,15-4,4 arasında değișen oranlarda bildirilmektedir ${ }^{2,3}$.

Lipomalar, gastrointestinal sistemde en sık sağ kolon lokalizasyonunda saptanırken, bunu sıklık sırasıyla sigmoid kolon, sol kolon ve transvers kolon izlemektedir. Özofagus ve mide yerleşimi nispeten daha nadir görülen lokalizasyonlardır ${ }^{4,5}$.

$\mathrm{Bu}$ çalışmada gastrointestinal sistem yerleşimli lipoma tanısı alan olguların sunulması ve bu tümörlerin klini- 
kopatolojik özelliklerinin literatür bilgileri eşliğinde değerlendirilmesini amaçlanmıştır.

\section{Gereç ve Yöntem}

Çalışmamıza Tıbbi Patoloji Anabilim Dalı arşivi retrospektif olarak taranarak histopatolojik tanısı verifiye edilmiş (endoskopik veya cerrahi yolla), GíS yerleşimli, lipoma tanısı alan 19 olgu dahil edildi. Olgulara ait hematoksilen-eozin ve immünohistokimyasal boyama yapılmış preparatlar yeniden değerlendirilerek histopatolojik özellikler kaydedildi.

Yaş, cinsiyet, tümör lokalizasyonu, tümör boyutu gibi demografik bilgiler ile anamnez, radyolojik görüntülemeler, tedavi, tedavi sonrası takip süreleri gibi klinik bilgiler elektronik hastane veri tabanı taranarak hasta dosyalarından elde edildi. Çalışmaya ait etik kurul Tıp Fakültesi Klinik Araştırmalar Etik Kurulu tarafından (2018-16/10) onayland.

\section{Bulgular}

Endoskopik veya cerrahi olarak histopatolojik tanıs1 verifiye edilmiş, GİS lipoma tanısı alan 19 olgu tespit edildi. Olgulara ait genel özellikler Tablo I'de özetlenmektedir. Olguların 11'i kadın $(\% 57,9)$, 8'i erkekti $(\% 42,1)$. Ortalama yaş $62,3 \pm 9$ y1l olarak saptand1.

Tablo I. Olguların klinikopatolojik bulguları $(\mathrm{n}=19)$

\begin{tabular}{|llc|}
\hline Değişkenler & & Olgu Sayısı \\
\hline Cinsiyet & Kadın & 11 \\
& Erkek & 8 \\
\hline Yaş & $\leq 50$ & 2 \\
& $50-70$ & 13 \\
& $\geq 70$ & 4 \\
\hline Tümör Çapı & $<5 \mathrm{~cm}$ & 15 \\
& $\geq 5 \mathrm{~cm}$ & 2 \\
\hline Klinik Prezentasyon & Karın ağrısı & 10 \\
& Barsak & 4 \\
& alışkanlıklarında & \\
& değişiklik & 2 \\
& Kanama & 1 \\
& Akıntı & 9 \\
& Hemikolektomi & 7 \\
& Polipektomi & 2 \\
& Eksizyonel Biyopsi & 1 \\
\hline Tedavi & Wedge Rezeksiyon &
\end{tabular}

Ortalama tümör çapı 2,5+1,6 cm idi. İki olgunun ise tümör çapına ulaşılamadı. Tümörlerden 14 'ü kolon, 3 'ü ince barsak, 1'i mide ve 1'i rektum yerleşimliydi. İnce barsak yerleşimli tümörlerden 2'si duodenum ve 1'i terminal ileum, kolon yerleşimli olgulardan ise 5'i inen kolon, 4'ü çekum, 4'ü çıkan kolon ve 1'i sigmoid kolonda lokalizeydi.

Klinik prezentasyon 10 olguda karın ağrısı, 4 olguda barsak alışkanlıklarında değişiklik, 2 olguda gastrointestinal sistem kanaması ve 1 olguda rektal akıntı şikayetiyleydi. 2 olgu ise insidental olarak saptandı.

On sekiz olguda tümör endoskopik muayeneyle, akut batın semptomlarıyla başvuran tek olguda ise yapılan acil operasyon sonrası saptand1. Endoskopik girişim yapılan olguların hiçbirinde işleme bağlı morbidite ya da mortalite gelişmedi.

Fizik muayene, radyolojik ve endoskopik değerlendirmeler doğrultusunda; 9 olguda polip, 5 olguda malignite, 1 olguda yabanc1 cisim ve 1 olguda lipoma ön tanıs1 ile operasyon planland1. Akut batın semptomlarıyla başvuran tek olguya çekumda nekroz ve palpable kitle ön tanısıyla acil cerrahi uygulandı. 2 olguda ise ön tanılara ulaşılamadı.

Toplam 7 olguda lipomalar endoskopik olarak yönetildi ve 6 olgu polipektomi ile lipomanın eksizyonu sonrası takibe alındı. Kolonoskopi sonucu terminal ileumda polip ön tanısıyla biyopsi yapılan $1 \mathrm{olgu}$ ise patoloji sonucunun lipoma gelmesi üzerine eksizyon uygulanmaksızın takip edildi..

Cerrahi olarak tedavi edilen toplam 12 olgu mevcuttu. Bunlardan biri akut batın nedeniyle acil olarak opere edilen, diğerleri ise elektif cerrahi uygulanan olgulard1. Ameliyat endikasyonu 5 olguda malignite şüphesi, 1 olguda endoskopik olarak çıkarılamayan polip, 1 olguda GİS kanama, 1 olguda polipozis koli ve 1 olguda obstrüksiyondu. Polipozis koli tanılı olguda lipoma yapilan kolonoskopi esnasında insidental olarak saptandı. En sık uygulanan cerrahi prosedür sağ hemikolektomi iken bunu sol hemikolektomi, subtotal kolektomi, laparoskopik sağ hemikolektomi ve laparoskopik mide wedge rezeksiyonu izlemekteydi. Sadece acil sağ hemikolektomi uygulanan olguda postoperatif komplikasyon (postoperatif pnömoni ve derin cerrahi alan enfeksiyonu) saptanırken, hiçbir olguda rekürrens veya mortalite gelişmedi.

Makroskopik değerlendirmede, tüm rezeksiyon materyallerinde mukozada ülserasyon oluşturmamış, iyi sınırlı, kesit yüzeyleri parlak sarı renkte soliter lezyon izlendi (Şekil 1). Histopatolojik incelemede, normal kolon mukozasının altında, submukozal büyüme gösteren, çevresinde ince fibröz kapsülün izlendiği ve fibröz bantlarla ayrılmış matür adipositlerden oluşan tümöral lezyon izlendi. Tümör hücrelerinde pleomorfizm, hiperkromatik nükleus, lipoblast formasyonu izlenmedi ve tümörde atipik mitotik figür ile nekroz saptanmadı. Angiolipoma tanısı alan inen kolon yerleşimli tek olgu dışında kalan tüm olgular klasik lipoma morfolojisindeydi (Şekil 2). 


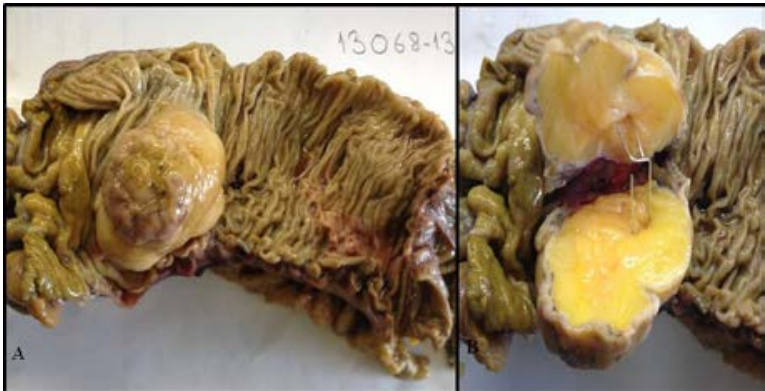

Sekil 1:

Makroskobik değerlendirme. Mukozada ülserasyon oluşturmamış, iyi sınırlı, kesit yüzeyleri parlak sarı renkte soliter lezyon

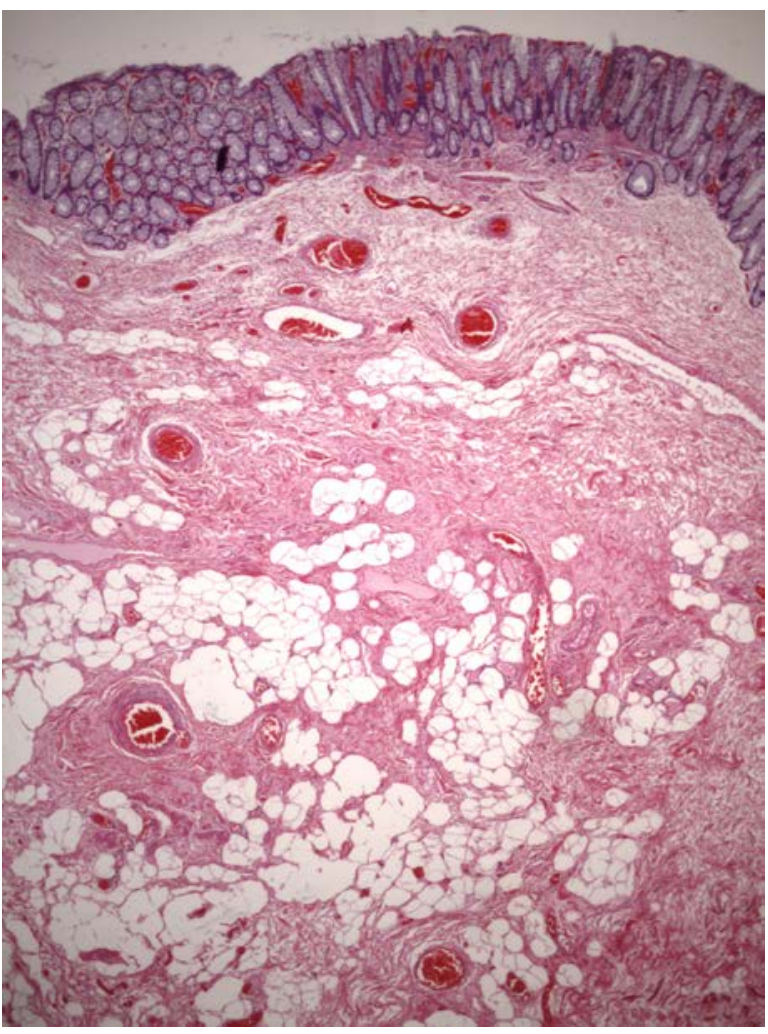

Sekil 2:

Submukozada matür adiposit ve konjesyone damar proliferasyonu içeren nodüler lezyon (H\&Ex25)

\section{Tartışma ve Sonuç}

Erişkin çağda en sık görülen yumuşak doku tümörleri olan lipomalar, gastrointestinal sistemde nispeten nadir görülen, gastrointestinal stromal tümör dışı mezenkimal tümörlerdir. Genellikle 5-6. dekadda tanı alan bu tümörler, kadınlarda erkeklere oranla daha sık görülmektedir ${ }^{4,6}$. Bu çalışmadaki olguların ortalama yaşı 62,3 olarak saptanmış olup kadınların erkeklere oranı 1,3 'tür.

Lipomaların etiyolojileri henüz net olarak aydınlatılamamıştır. Endokrin ve genetik etkenlerin yanı sıra travma gibi çeşitli durumlar da etiyolojide suçlanan etkenler arasındadır. Bazı yayınlarda gastrointestinal sistem yerleşimli lipomaların kronik inflamasyona sekonder gelişen psodö lezyonlar olduğunu öne sürülmektedir ${ }^{7,8}$.

Gastrointestinal sistemde herhangi bir lokalizasyonda saptanabilen lipomaların en sık yerleşim yeri kolondur (sırasıyla çekum, sağ kolon ve sigmoid kolon). Kolon yerleşimini \%20-25 sıklıkla ince barsak ve \%5 sıklıkla mide yerleşimi izlemektedir. Lipomalar midede genellikle antrum lokalizasyonunda saptanırken oldukça nadir görüldüğü özofagusta üst 1/3'lük kısma yerleşmektedir ${ }^{9}$. Bu serideki mide yerleşimli tek olguda tümör korpusta lokalizedir. Literatürle uyumlu olarak 14 olguyla kolon lokalizasyonu en sık yerleşim yeri olup, lipomaların 8'i sağ kolon, 6'sı ise sol kolon yerleşimlidir.

Lipomalar genellikle soliter submukozal lezyonlardir ancak nadiren intermusküler veya subserozal yerleşimli ya da multiple sayıda (özelikle çekum lokalizasyonunda) olabilmektedir. Sesil ya da pedinküle formda saptanabilir. Boyutları değişken olmakla birlikte genellikle $3-5 \mathrm{~cm}$ arasındadır. Literatürde $20 \mathrm{~cm}$ 'e varan olgularda bildirilmiştir ${ }^{2,10,11}$. Bu çalışmada yer alan tümörlerin ortalama çapı $2,5 \mathrm{~cm}$ 'dir. Tümörlerin 2'si intramusküler kalan tamamı ise submukozal yerleşimlidir.

Lipomaların yavaş büyüme özelliği nedeniyle olgular başlangıçta genellikle asemptomatiktir ve insidental olarak saptanır. Semptomatik hale genellikle tümör boyutu 2 cm'i aştı̆̆ında geçmeye başlarlar ve olgularda gastrointestinal kanama, anemi, karın ağrısı, intusepsiyon, obstrüksiyon, dispeptik şikayetler ile barsak alışkanlıklarında değişiklikler görülür. Gastrointestinal kanama tümörün üzerini örten mukozanın ülsere olması sonucu meydana gelir ve gizli kanama olabileceği gibi abondan da olabilmektedir ${ }^{12,13}$. Jiang ve ark.'larının literatürde yer alan kolon yerleşimli 33 olguyu derledikleri yayınlarında $\% 54,5$ oran ile rektal kanama en sık şikayet olarak saptanmıştır. Diğer sık rastlanan şikayetler ise karın ağrısı $(\% 42,4)$ ve barsak alışkanlıklarında değişikliklerdir $(\% 24,2)^{14}$. Bu çalışmadaki olgularda ise en sık klinik başvuru nedeni karın ağrısıdır.

Bilgisayarlı tomografi (BT), manyetik rezonans veya endoskopik ultrasonografi gibi çeşitli radyolojik görüntüleme yöntemleri tanıya yardımcıdır. Küçük boyutlu tümörler ( 2 cm'in altı) özellikle BT görüntülemelerde tanı zorluğu yaratsa da -70 ile $-120 \mathrm{HU}$ arasındaki değerleri lipoma için tanısal kabul edilmektedir. Endoskopik ultrasonografi ile yapılan değerlendirmelerde genellikle submukozal yerleşimli hiperekoik lezyon şeklinde saptanırlar. Kolonoskopide saplı veya sapsız, düzgün yüzeyli, submukozal yerleşimli lezyonlar şeklinde saptanırlar. Forseps ile tutulan lezyonun bırakıldığında eski haline dönmesi önemli bir özelliktir. Biyopsi ile tanı imkanı, özellikle 2,5 
cm'in altında ve saplı lezyonlarda polipektomi ile tedavi olanağı sunması kolonoskopinin avantajları iken submukozal yerleşimi nedeniyle özellikle yüzeyel biyopsilerin tanı için yetersiz kalabileceği de unutulmamalıdır ${ }^{1,2,7}$. Bu seride radyolojik görüntülemelerine ulaşılabilen tümörler düzgün sınırlı, yumuşak doku ekojenitesinde kitle lezyonu şeklinde bulgu vermekteydi.

Mikroskobik olarak submukozal yerleşimli, matür lipositlerden oluşan, yer yer fibröz septaların izlendiğ iyi sınırlı benign neoplazilerdir. Özellikle büyük boyutlara ulaşan lipomalarda ülserasyon, iltihabi granülasyon dokusu ve yağ nekrozu da saptanabilmektedir. Lipomaların anjiolipoma, kondroid lipoma, myolipoma, myelolipoma, fibrolipoma, fibrohistiyositik lipoma, iğsi hücreli lipoma ve pleomorfik lipoma gibi çeşitli varyantları da tanımlanmıștır. Ayırıcı tanıda ilk sırada yer alan liposarkomada gözlenen hiperkromatik nükleuslu hücreler, bizar hücreler, lipoblastlar, lipositler arası boyut ve şekil farklılıkları, geniş fibröz bantlar ile artmış mitoz gibi histopatolojik bulgular ayrımda yardımcidır. Gastrointestinal sistem lipomalarda malign transformasyon oldukça nadir görülürken, nüks beklenen bir durum değildir ${ }^{15,16}$. Ayrıca literatürde gastrointestinal sistem kaynaklı lipoma ve adenokarsinoma birlikteliği de bildirilmiştir ${ }^{17}$. Bu çalışmada 19 olgudan 1'i anjiolipoma özelliğindeyken, diğer olgular klasik lipoma morfolojisindedir.

Moleküler genetik incelemelerde lipomalarda, 12q1315'de lokalize HMGA2/HMGIC'in füzyon transkripti ve nadiren kromozomal değişiklikler gösterilmiştir ${ }^{16,18}$. Insidental olarak saptanan lipoma olgularında herhangi bir tedavi veya takip gerekmezken, semptomatik olgularda tümörün elektif şartlarda endoskopik, laparoskopik veya laparotomik yöntemlerle çıkarılması gerekmektedir $^{19}$.

$\mathrm{Bu}$ çalışmanın en önemli kısıtlılığı retrospektif dizaynı ve olgu sayısının az olmasıdır ancak mevcut demografik, klinik ve patolojik bulgular literatür ile uyumludur. Sonuç olarak, küçük boyutlu olduklarında herhangi bir semptoma neden olmaksızın insidental olarak saptanan lipomalar, büyük boyutlara ulaştıklarında gastrointestinal sistem malignitelerini taklit eder özellikler kazanabilmektedir. Gastrointestinal sistemde özellikle submukozal yerleşimli lezyonların ayırıcı tanısında nadir görülen lipomalarda akla getirilmelidir. Gereksiz rezeksiyonların önlenmesi adına operasyon öncesinde olgular mutlaka uygun radyolojik ve endoskopik yöntemlerle incelenmeli, malignite ekarte edilmeli ve komplikasyongelişimini en aza indirecek en uygun tedavi seçeneği açısından değerlendirilmelidir.

Etik Kurul Onay Bilgisi:

Onaylayan Kurul: Uludağ Üniversitesi Tıp Fakültesi Klinik Araştırmalar Etik Kurulu.

Onay Tarihi: 17.09.2018

Karar No: 2018-16/10
Araştırmacı Katkı Beyanı: Fikir ve tasarım: M.Ö., Ö.Y., N.U.; Veri toplama ve işleme: M.Ö., Ö.I., T.Y.; Analiz ve verilerin yorumlanmasi: M.Ö., N.U., Ö.I., Ö.Y.; Makalenin önemli bölümlerinin yazılmasi: M.Ö., N.U., Ö.I.

Destek ve Teşekkür Beyanı: Bu makalede yer alan çalışmaya finansal destek sağlayan bir kişi ya da kurum bulunmamaktadır.

Çıkar Çatışması Beyanı: Makale yazarının çıkar çatışması beyanı yoktur.

\section{Kaynaklar}

1. Kang HC, Menias CO, Gaballah AH, Shroff S, Taggart MW, Garg N, Elsayes KM. Beyond the GIST: mesenchymal tumors of the stomach. Radiographics. 2013 Oct;33(6):1673-90. doi: 10.1148/rg.336135507.

2. Tascilar O, Cakmak GK, Gun BD, Ucan AH, Balbaloglu H, Cesur A, Emre AU, Comert M, Erdem LO, Aydemir S. Clinical evaluation of submucosal colonic lipomas: decision making. World J Gastroenterol. 2006 Aug 21;12(31):5075-7.

3. Chung Y, Ho Y, Nyam D, et al: Management of colonic lipomas. Aust NZ J Surg 68:133-5, 1998.

4. Gould DJ, Anne Morrison C, Liscum KR, Silberfein EJ. A lipoma of the transverse colon causing intermittent obstruction: a rare cause for surgical intervention. Gastroenterol Hepatol (N Y). 2011 Jul;7(7):487-90.

5. Aytaç B, Yerci Ö, Gürel S, Ferik Z. Colonic Lipomas Mimicking Colon Cancer. Turk Patoloji Derg. 2010,26(3):196-9.

6. Zhang H, Cong JC, Chen CS, Qiao L, Liu EQ. Submucous colon lipoma: a case report and review of the literature. World $\mathrm{J}$ Gastroenterol. 2005 May 28;11(20):3167-9.

7. Chehade HH, Zbibo RH, Nasreddine W, Abtar HK. Large ileocecal submucosal lipoma presenting as hematochezia, a case report and review of literature. Int J Surg Case Rep. 2015;10:1-4.

8. Eryılmaz MA, Yücel A, Yücel H, Arıcıgil M. Cervico-Thoracic Giant Lipoma in a Child. Turk Arch Otorhinolaryngol. 2016 Jun;54(2):82-85. doi: 10.5152/tao.2016.1620. Epub 2016 Jun 1.

9. Thompson WM. Imaging and findings of lipomas of the gastrointestinal tract. AJR Am J Roentgenol. 2005 Apr;184(4):116371.

10. Dassanayake SUB, Dinamithra NP, Nawarathne NMM. Submucosal lipoma of the sigmoid colon as a rare cause of mucoid diarrhea: a case report. J Med Case Rep. 2016 Jan 20;10:17.

11. Narindra Rajaonarison Ny Ony L, Ahmad A, Bruneton JN. Lipomas of the digestive tract: General aspects and imaging. Cureus. 2014 September;6(9): e208.

12. Lin Y, Chiu N, Li AF, Liu C, Chou Y, Chiou Y. Unusual gastric tumors and tumor-like lesions: Radiological with pathological correlation and literature review. World J Gastroenterol 2017 April 14; 23(14): 2493-2504.

13. Val-Bernal JF, Hermana S, Gómez-Román JJ. Incidental, lowfat variant of spindle cell lipoma: a novel tumour of the small intestine. Pol J Pathol. 2018;69(1):82-86. doi: 10.5114/pjp.2018.75341.

14. Jiang L, Jiang LS, Li FY, Ye H, Li N, Cheng NS, Zhou Y. Giant submucosal lipoma located in the descending colon: a case report and review of the literature. World J Gastroenterol. 2007 Nov 14;13(42):5664-7.

15. Fletcher CDM, Bridge JA, Hogendoorn P, Mertens F. World Health Organization Classification of Tumours of Soft Tissue and Bone: Adipocytic tumors 4th ed. Lyon, France: IARC Press, 2013; 20-43. 


\section{Gastrointestinal Yerleșimli Lipomalar}

16. Fisher C, Montgomery EA, Thway K. Biopsy Interpretation Series Biopsy Interpretation of the Soft tissue tumors. 2th ed. Philadelphia;2011. 355-402.

17. Namikawa T, Munekage E, Mizuta H, Kobayashi M, Saibara T, Hanazaki K. Simultaneous occurrence of gastric lipoma an early gastric cancer. Endoscopy. 2014;46 Suppl 1 UCTN:E338
18. Henderson-Jackson EB, Bui MM. Molecular Pathology of SoftTissue Neoplasms and Its Role in Clinical Practice. Cancer Control. 2015 Apr;22(2):186-92.

19. El-Dika S, Vahabzadeh A, Karageorge L, Kinsey A. A large pedunculated lipoma endoscopically resected with the assistance of a detachable nylon endoloop. Gastroenterol Hepatol (N Y). 2007 Nov;3(11):880-1. 
